\title{
TARGET BACA: ALTERNATIF PENUMBUHAN MINAT BACA SASTRA
}

\section{READING TARGET: ANALTERNATIVE FOR INCREASING READING HABIT MOTIVATION}

\author{
Syaiful Bahri \\ Kantor Bahasa Provinsi Nusa Tenggara Barat
}

Naskah masuk tanggal: 1 Mei 2012

Revisi terakhir tanggal: 20 November 2012

\begin{abstract}
The low reading habit nowadays effects to the stagnant of learning of literature. To cope with the problem, it is necessary to strengthen the reading habit motivation, especially those related to reading literature works. Therefore, an alternative offered to the teachers of Bahasa dan Sastra Indonesia in school which is known as reading target (target baca). The purpose of this target is to increase the reading habit among students. This target is conducted through the process of dealing, depositing, and writing. Teachers play important rule for the success of the target by acting as motivator who love literature as well.
\end{abstract}

Keyword: reading target, reading habit, literature

\begin{abstract}
Abstrak
Kebekuan pembelajaran sastra tidak terlepas dari faktor lemahnya budaya baca. Artinya, guna memecahkan kebekuan pembelajaran sastra, kegiatan membaca (khususnya sastra) harus dibudayakan.Target baca.Merupakan salah satu alternatif bagi upaya pembudayaan membaca di kalangan siswa.Kegiatan tawaran bagi guru Bahasa dan Sastra Indonesia ini dilaksanakan melalui proses membuat kesepakatan, penyetoran, dan penulisan. Masing-masing proses tersebut akan terlaksana dengan baik jika guru yang bertindak sebagai motivator juga mencintai sastra.
\end{abstract}

Kata kunci: target baca, minat baca, sastra

\section{Pendahuluan}

Penyair Indonesia, Taufik Ismail, memaparkan hasil survei yang berkaitan dengan pengajaran sastra SMU di 13 negara lain. Survei itu berkaitan dengan perbandingan jumlah buku yang wajib atau pernah dibaca siswa setingkat SMA di Indonesia dengan 13 negara lain, seperti Malaysia, Singapura, Jepang. Brunai, dan lain-lain. Dari survei itu diperoleh data rata-rata siswa setingkat SMA di negara lain telah membaca 6-32 judul buku setiap sekolah, sedangkan Indonesia 0 judul buku (Maarif dalam Endraswara, 2002). ${ }^{1}$

Lebih jauh, memang Endraswara mengemukakan bahwa hasil survei tersebut perlu dipertanyakan keabsahannya. Namun, jika kita merenung dan mengingat-ingat rentang waktu yang telah kita tempuh untuk melewati jenjang-jenjang sekolah, tiap-tiap jenjang itu jarang atau bisa dikatakan tidak pernah dituntut untuk membaca, khususnya membaca karya 
sastra. Ketika materi sastra yang menuntut pembacaan karya sastra, umumnya guru/siswa mengambil jalan pintas dengan hanya membaca sinopsis. Dengan begitu, kita akan kesulitan merasakan karya sastra sebagai pemerkaya batin.

Dalam beberapa kurikulum yang telah diterapkan, misalnya KTSP, disebutkan bahwa pada akhir pendidikan SMA/MA peserta didik diharapkan telah membaca minimal 15 buku sastra dan nonsastra. Akan tetapi, dalam pelaksanaannya terkadang diabaikan dengan berbagai alasan.

Kegiatan membaca, khususnya karya sastra, terkalahkan oleh kegiatan menonton acara-acara televisi dengan tayangan yang tak pernah berhenti. Kondisi seperti ini terjadi di tengah masyarakat yang masih berada dalam budaya lisan. Idealnya, kemapanan budaya lisan akan diikuti budaya tulis. Setelah budaya baca mencapai kemapanan, baru kemudian dilanjutkan dengan budaya televisi.

Kondisi di atas memang sudah terjadi dan tidak bisa dihindari. Hal yang terpenting sekarang adalah upaya untuk memunculkan budaya baca yang telah terlewatkan oleh budaya televisi. Sekolah-khususnya guru Bahasa dan Sastra Indonesia-harus mengambil peranan guna mendorong munculnya budaya baca ini.

Salah satu materi pelajaran yang memiliki potensi untuk diolah sebagai pendorong budaya baca adalah sastra. Dalam sastra terdapat novel, cerpen, puisi, maupun drama yang berdasar pada cerita. Cerita memiliki peranan penting sebagai pendorong tumbuhnya rasa senang untuk membaca. Walsh dalam Sarumpaet ${ }^{2}$ mengatakan bahwa cerita memiliki tempat yang signifikan dalam perkembangan bahasa anak dan keterampilan literernya, juga pengembangan psikologis dan emosinya. Melalui pemanfaatan cerita, anak-anak menunjukkan sikap yang positif terhadap pembelajaran menulis dan membaca, dan kemampuan mereka dalam kedua area itu bertambah dan bertumbuh. Bahasa lisan mereka juga lebih fasih. Melalui perkenalan mereka dengan cerita, umumnya harga diri mereka juga membaik dan mereka semakin gembira dan lebih percaya diri dalam hal kemampuan menulis dan membaca serta mengambil bagian dalam diskusi. Berangkat dari membaca cerita dalam karya sastra inilah diharapkan akan memunculkan kesenangan membaca dan menjadikannya sebagai kebutuhan. Jika membaca sudah menjadi kebutuhan, setiap hari akan diisi dengan kegiatan membaca. Dari kesukaan membaca sastra inilah diharapkan akan berimbas pada bacaan-bacaan nonsastra.

Salah satu alternatif pendorong kegiatan membaca-khususnya sastra - adalah kegiatan yang penulis namakan target baca. Dikatakan target karena kegiatan ini berlangsung secara terus-menerus dan dengan penyelesaian yang tegas. Kegiatan ini ditujukan kepada siswa 
SMP maupun SMA yang intinya mengharuskan siswa untuk membaca karya sastra dalam jangka waktu yang telah ditentukan. Pelaksanaan kegiatan ini diharapkan berkelanjutan, yaitu sejak siswa mengawali hingga menyelesaikan pendidikannya dalam tiap jenjang. Konsep target baca itulah yang akan dijabarkan dalam artikel ini. Hal itu menjadi tawaran model yang diharapkan bisa dilaksanakan dalam dunia pengajaran, terutama jenjang SMP dan SMA.

\section{Pembahasan}

\subsection{Pengajar atau Guru}

Kunci utama kegiatan ini adalah guru yang memiliki kecintaan terhadap karya sastra. Dari kecintaan ini diharapkan akan tumbuh motivasi dan kesenangan untuk membimbing, mengarahkan, dan mengontrol secara terusmenerus kegiatan apresiasi sastra yang dilakukan oleh siswa. Kegiatan ini sangat mengharapkan sosok guru sastra seperti yang digambarkan Rusyana (dalam Sarumpaet) ${ }^{3}$, yaitu guru yang mempunyai semangat, kecintaan, dan kegemaran untuk membaca dan mengikuti perkembangan pengetahuan tentang sastra. Selain itu, ia juga mampu dalam kritik sastra.

Rasa cinta terhadap sastra ini akan menjadi modal yang akan menumbuhkan motivasi bagi guru untuk terus melakukan pembinaan dan menemukan terobosanterobosan sebagai upaya untuk menumbuhkan kecintaan/minat siswa terhadap sastra.

Sarumpaet ${ }^{4}$ menyebutkan beberapa ciri yang menunjukkan bahwa seseorang dikatakan sebagai pencinta atau peminat sastra, yaitu (1) gemar membaca, mendengarkan, dan menonton pertunjukan sastra; (2) gemar membicarakan dan mendialogkan kepada orang lain dari apa yang dilihat, dirasakan, dan dihayati dalam karya sastra; (3) suka mengumpulkan karya-karya sastra, mengkliping beberapa karya yang menurut minatnya; (4) sering membaca ulasan, sorotan, timbangan sastra yang ada di media massa; dan (5) gemar mengikuti aneka macam lomba sastra untuk meningkatkan dan menguji kemampuan.

Selain motivasi pribadi, dalam kegiatan target baca baca ini juga dibutuhkan motivasi dari sekolah, khususnya guru-guru bahasa Indonesia yang ada dalam satu sekolah. Hal itu dikarenakan kegiatan ini membutuhkan kontrol yang akan dilakukan sejak anak masuk hingga menamatkan sekolahnya.

Oleh karena itu, sebelum pelaksanaan program ini, sebaiknya diadakan kesepakatan bersama antara guru-guru bahasa Indonesia dalam satu sekolah. 
Dengan begitu, siapapun yang menjadi pengajar bahasa Indonesia pada masing-masing jenjang yang dilalui siswa, program ini terus dilaksanakan secara berkesinambungan. Kepala sekolah yang notabene sebagai pemimpin di sekolah juga sangat diperlukan perannya sebagai pengontrol dan pemberi motivasi kepada guru-guru bahasa Indonesia untuk melaksanakan program tersebut.

\subsection{Proses Pelaksanaan Target Baca}

Sebagaimana telah dijelaskan sebelumnya, penggunaan kata target di sini menunjukkan bahwa kegiatan ini dilakukan secara berkelanjutan, tidak sepotongsepotong. Kegiatan ini berlangsung sejak anak mulai memasuki sekolah di kelas awal pada jenjang tertentu. Dari sanalah pemantauan kegiatan dilakukan sampai anak menamatkan pendidikan.

Jika dijabarkan secara terperinci, target baca ini dapat dilaksanakan melalui beberapa langkah. Langkah-langkah tersebut merupakan urutan yang akan dijabarkan satu persatu.

\subsubsection{Membuat Kesepakatan}

Langkah awal yang dilakukan dalam kegiatan ini adalah membuat kesepakatan.
Kesepakatan yang dimaksud, yakni kesepakatan dengan guruguru bahasa dan sastra Indonesia yang ada dalam satu sekolah dan kesepakatan yang dilakukan oleh guru dengan siswa di masingmasing kelas.

Pertama-tama, dalam pelaksanaan target baca ini, guruguru bahasa dan sastra Indonesia dalam satu sekolah membuat kesepakatan untuk melaksanakan kegiatan target baca ini secara bersama-sama. Hal ini sangat diperlukan karena dalam satu sekolah biasanya masing-masing tingkatan kelas dibimbing oleh guru bahasa dan sastra Indonesia yang berbeda. Dengan begitu, bisa dikatakan bahwa target baca ini merupakan program bersama untuk menumbuhkan motivasi siswa dalam membaca.

Kesepakatan ini merupakan upaya menyatukan pikiran dan menjalin komunikasi antar guru, khususnya guru bahasa Indonesia. Membudayakan komunikasi seperti ini diharapkan mampu menumbuhkan keterbukaan sehingga diskusi yang berkaitan dengan pengajaran akan terus berlanjut dalam suasana yang penuh keakraban.

Setelah itu, kegiatan kedua yang harus dilakukan adalah membuat kesepakatan dengan siswa tentang jumlah novel, 
cerpen, maupun puisi yang harus dibaca siswa dalam satu semester. Misalnya, dalam satu semester siswa diwajibkan membaca tiga judul novel, empat cerpen, dan enam judul puisi. Penentuan jumlah bacaan ini harus disesuaikan dengan kondisi buku di perpustakaan maupun ketersediaan buku-buku di toko buku terdekat yang bisa dijangkau oleh siswa. Jika memungkinkan, guru bisa meminjamkan novel, buku kumpulan puisi, cerpen, atau drama yang dimiliki. Pemberian pinjaman ini juga akan menumbuhkan kedekatan emosi antara guru dengan siswa.

Selain kesepakatan jumlah buku yang harus dibaca, guru juga harus menyepakati dan menjelaskan proses atau mekanisme penyetoran hasil bacaan. Dalam pembuatan kesepakatan ini, guru harus mengingat tujuan utama dari target ini, yaitu menciptakan kesenangan membaca dalam diri siswa. Untuk itu, penyetoran ini jangan sampai membuat siswa merasa terbebani.

Pada dasarnya, segala hal yang berkaitan dengan kesepakatan bersama siswa ini juga harus dibicarakan dalam dalam membangun kesepakatan antarguru. Akan tetapi, dalam kesepakatan antarguru tersebut hanya berupa alternatif-alternatif yang akan coba ditawarkan dan didiskusikan bersama dengan siswa. Kegiatan seperti ini juga bermanfaat sebagai upaya melibatkan siswa secara langsung dalam pengambilan keputusan. Dengan begitu diharapkan akan muncul perasaan dihargai dan berdampak pada perasaan ikhlas dan senang dalam melaksanakan suatu kegiatan/program.

\subsubsection{Penyetoran}

Dalam kegiatan penyetoran, siswa ditugaskan hanya menceritakan isi cerita dari cerpen atau novel yang dibaca, sedangkan untuk puisi hanya menjelaskan makna atau penafsiran siswa terhadap puisi yang telah dibacanya. Dalam penyetoran tersebut, siswa diharapkan membawa buku novel atau cerpen yang telah dibaca dan akan disetorkan. Hal itu sebagai bukti bahwa mereka telah membacanya secara keseluruhan, bukan hanya membaca sinopsis. Agar lebih meyakinkan, dalam proses penyetoran ini, guru bisa menyela cerita siswa dengan pertanyaan-pertanyaan yang berkaitan dengan penguasaan siswa terhadap cerita. Dengan begitu, secara ideal tentunya guru lebih dahulu dituntut untuk membaca karya sastra tersebut. Meskipun pernah membaca dan 
mengetahui alur cerita, guru harus mampu memosisikan diri sebagai orang yang ingin tahu alur cerita. Hal ini bertujuan agar tidak muncul kesan interogasi.

Penyetoran dilakukan di luar jam pelajaran. Pelaksanaannya tidak ditentukan oleh guru, siswalah yang menentukan waktu penyetoran tersebut dilakukan, bergantung kesiapan mereka. Guru hanya menentukan rentang waktu penyetoran, misalnya sejak awal semester sampai akhir sebelum ujian semester.

Berdasarkan konsep tersebut, guru harus selalu siap menerima setoran siswa. Perlu diperhatikan bahwa dalam penyetoran ini, guru harus membangun suasana akrab dengan siswa. Dengan begitu diharapkan akan tercipta suasana santai, tanpa ketegangan. Artinya, suasana dalam kegiatan penyetoran harus berbeda dengan suasana ketika terjadi proses belajar-mengajar di dalam kelas. Dengan begitu diharapkan siswa akan terus termotivasi untuk melakukan penyetoran bacaannya.

Dampak dari model kegiatan seperti ini adalah terbangunnya komunikasi akrab antara guru dengan siswa. Kesan bahwa guru memiliki sifat yang kaku dan tegang akan terkikis secara perlahan. Jika suasana seperti ini sudah terbentuk, kegiatan belajar-mengajar akan menjadi sebuah kegiatan yang menyenangkan. Ikatan batin antara guru dan siswa pun akan terjalin dengan kuat.

\subsubsection{Penulisan}

Setelah siswa menyetorkan hasil bacaannya, guru mengambil buku novel atau cerpen yang telah dibaca siswa tersebut. Siswa kemudian ditugaskan membuat sinopsis cerita dalam bentuk tulisan. Dengan begitu diharapkan siswa berkreasi memindahkan ide yang telah disampaikan dalam bentuk lisan ke dalam bentuk tulisan. Buku novel atau cerpen tersebut akan dikembalikan setelah dalam jangka waktu tertentu siswa menyerahkan tulisan berupa sinopsis tersebut.

Sama halnya dengan prosa, siswa yang telah menyetorkan tafsiran puisinya juga harus menuangkan hasil tafsiran tersebut dalam bentuk tulisan. Pemindahan dari bahasa lisan ke bahasa tulis ini diharapkan akan mampu melatih siswa menuangkan ide atau gagasan dalam bahasa tulis.

Pada tahap selanjutnya, hasil penyusunan tulisan ini bisa dipergunakan sebagai bahan untuk pemberian materi yang 
66|Mabasan, Vol. 6 No. 1, Juli-Desember 2012

berkaitan dengan kalimat atau ejaan. Dengan begitu, siswa dapat melihat dan mengukur secara langsung tingkat kemampuan menulis yang mereka miliki. Model pembelajaran seperti ini menurut penulis akan lebih melekat dalam ingatan siswa dibandingkan dengan mengambilkan dari bahan bacaan lain yang belum tentu dekat dan menarik bagi mereka. Model seperti ini diharapkan akan mampu meningkatkan motivasi belajar pada diri siswa.

Demikianlah beberapa langkah yang penulis tawarkan berkaitan dengan kegiatan target baca. Kegiatan target baca ini kemudian dilanjutkan pada semester berikutnya. Dengan begitu, jika dalam satu tahun siswa sudah membaca enam judul novel, delapan judul cerpen, dan dua belas judul puisi. Dalam tiga tahun, siswa sudah membaca karya sastra tiga kali lipat. Pembacaan karya sastra yang cukup banyak tersebut diharapkan akan menciptakan pengalaman tersendiri dalam diri siswa.

Dengan terus menggauli sastra, diharapkan siswa sekurang-kurangnya melalui empat tingkatan proses apresiasi sastra, yaitu menggemari, menikmati, mereaksi, dan memproduksi. Dalam tahap menggemari diharapkan siswaakan tertarik dan ingin membaca sastra. Ketertarikan untuk membaca merupakan indikator yang menunjukkan bahwa mereka gemar membaca sastra. Indikator tersebut akan semakin dikuatkan jika mereka selalu 'haus' dan 'memburu'setiap karya baru dengan luapan keinginan yang demikian besar untuk membacanya. Jika kondisi seperti itu sudah tumbuh dalam diri, maka hal itu menjadi satu ciri bahwa telah tumbuh kesadaran dan kesanggupan untuk melakukan apresiasi dalam tahap berikutnya.

Dalam tingkatan proses menikmati, pada diri subjek didik diharapkan mulai mucul daya/dorongan batin bahwa karya sastra memiliki manfaat tertentu. Karyasastra yang dibaca akan mampu menghibur dan membuahkan rasa manis dalam dirinya. Membaca karya sastra bagaikan orang yang telah "lapar" ketika akan berbuka puasa. Kalau sikap ini sudah tumbuh, tanpa ada yang menyuruh, jelas ada rasa nikmat ketika berolah sastra.

Pada tingkatan proses mereaksi, siswa akan mampu memberikan respon terhadap karya sastra. Respon ini tergantung pengalaman jiwa 
Target Baca: Alternatif... (Syaiful Bahri) |67

masing-masing. Kedalaman pemahaman mereka terhadap karya juga akan menentukan respon. Kalau memahami karya sastra disertai penghayatan emosional, tentu akan berbeda reaksinya dibanding yang membaca sekedar mengisi waktu luang.

Tahap selanjutnya, yakni tahap produksi. Pada tahap ini siswa akan terdorong untuk menciptakan karya seperti yang dibacanya. Jika subjek didik telah berkeinginan menciptakan karya sejenis, berarti apresiasi telah menunjukkan puncaknya.

Semua tingkatan tersebut merupakan suatu lingkaran yang saling mendukung satu sama lain. Sarumpaet $^{5}$ mengatakan bahwa belajar tuntas dalam sastra tak sekedar berhenti pada membaca sastra lalu selesai. Namun, setelah membaca, baru menghayati, mengkritik, dan memproduksi. Jadi, ada semacam lingkaran yang tak putus dari proses kreativitas sastra.

Di akhir tahun ajaran, sekolah bisa membuat kegiatankegiatan apresiasi sastra yang membuat siswa terus termotivasi dan terdorong untuk membaca, misalnya mendatangkan pengarang untuk berbicara tentang pengalaman mereka tentang pentingnya membaca dalam penciptaan karyanya.

Dalam kegiatan belajar mengajar, guru pun bisa memanfaatkan hasil bacaan sastra tersebut untuk mendukung materi-materi yang berkaitan dengan apresiasi maupun kajian sastra dalam mata pelajaran bahasa dan sastra Indonesia. Akhirnya, kita tidak mendengar lagi kegiatan apresiasi maupun kajian sastra dilakukan hanya dengan membaca sinopsis karya sastra.

\section{Simpulan}

Target baca merupakan sebuah ide yang berupaya untuk meningkatkan minat untuk membaca, terutama membaca sastra. Ide tersebut tentunya akan berjalan dengan baik jika komando pelaksana (guru) juga memiliki minat dan kecintaan yang besar terhadap sastra. Tahap demi tahap pelaksanaan merupakan sebuah lingkaran yang berjejang. Jika setiap tahap betul-betul dilaksanakan, semua tahap tersebut akan saling mendukung dan memunculkan motivasi untuk beralih pada tahap berikutnya. 
68|Mabasan, Vol. 6 No. 1, Juli-Desember 2012

\section{DAFTAR PUSTAKA}

${ }^{1}$ Endraswara, Riris K. Toha (Ed.). 2002. Sastra Masuk Sekolah. Magelang: Indonesiatera

${ }^{2}$ Sarumpaet, Riris K. Toha (Ed.). 2002. Sastra Masuk Sekolah. Magelang: Indonesiatera

${ }^{3}$ Sarumpaet, Riris K. Toha (Ed.). 2002. Sastra Masuk Sekolah. Magelang: Indonesiatera

${ }^{4}$ Sarumpaet, Riris K. Toha (Ed.). 2002. Sastra Masuk Sekolah. Magelang: Indonesiatera

${ }^{5}$ Sarumpaet, Riris K. Toha (Ed.). 2002. Sastra Masuk Sekolah. Magelang: Indonesiatera 